Article

\title{
Protein Formulations Containing Polysorbates: Are Metal Chelators Needed at All?
}

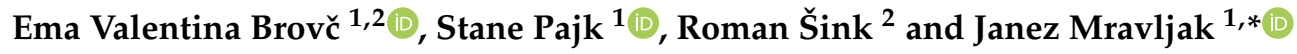 \\ 1 Faculty of Pharmacy, University of Ljubljana, Aškerčeva 7, SI-1000 Ljubljana, Slovenia; \\ ema.valentina.brovc@ffa.uni-lj.si (E.V.B.); stane.pajk@ffa.uni-lj.si (S.P.) \\ 2 Global Drug Development Technical Research and Development, Novartis, Biologics Technical Development \\ Mengeš, Drug Product Development, Lek Pharmaceuticals d.d., Kolodvorska 27, SI-1234 Mengeš, Slovenia; \\ roman.sink@novartis.com \\ * Correspondence: janez.mravljak@ffa.uni-lj.si; Tel.: +386-1-4769500
}

Received: 30 April 2020; Accepted: 18 May 2020; Published: 20 May 2020

check for updates

\begin{abstract}
Proteins are prone to post-translational modifications at specific sites, which can affect their physicochemical properties, and consequently also their safety and efficacy. Sources of post-translational modifications include oxygen and reactive oxygen species. Additionally, catalytic amounts of $\mathrm{Fe}(\mathrm{II})$ or $\mathrm{Cu}(\mathrm{I})$ can promote increased activities of reactive oxygen species, and thus catalyse the production of particularly reactive hydroxyl radicals. When oxidative post-translational modifications are detected in the biopharmaceutical industry, it is common practice to add chelators to the formulation. However, the resultant complexes with metals can be even more damaging. Indeed, this is supported here using an ascorbate redox system assay and peptide mapping. Ethylenediaminetetraacetic acid (EDTA) addition strongly accelerated the formation of hydroxyl radicals in an iron-ascorbate system, while diethylenetriaminepentaacetic acid (DTPA) addition did not. When Fe(III) was substituted with $\mathrm{Cu}(\mathrm{II})$, EDTA addition almost stopped hydroxyl radical production, whereas DTPA addition showed continued production, but at a reduced rate. Further, EDTA accelerated metal-catalysed oxidation of proteins, and thus did not protect them from Fe-mediated oxidative damage. As every formulation is unique, justification for EDTA or DTPA addition should be based on experimental data and not common practice.
\end{abstract}

Keywords: proteins; oxidation; Fenton reaction; free radicals; chelating agents; polysorbates

\section{Introduction}

Oxidation is one of the major chemical degradation pathways for protein pharmaceuticals, as it can result in covalent modifications to the amino-acid residues in proteins. Several amino acids are susceptible to oxidation. This includes, in particular, methionine and cysteine, and also histidine, tryptophan and tyrosine, due to their high reactivities with various reactive oxygen species. Oxidation of proteins can occur during the production steps, with oxygen concentrations that are too high or too low in cell culture media implicated in increased oxidative modifications [1-3]. As well as the production and purification processes, any excipients that are added during the formulation of a pharmaceutical and its subsequent storage conditions can directly or indirectly result in oxidative damage. For instance, polysorbates and polyethylene glycols can be contaminated with hydrogen peroxide $\left(\mathrm{H}_{2} \mathrm{O}_{2}\right)$, and additionally, these excipients can undergo spontaneous autooxidation in the presence of dissolved oxygen, which can be accelerated by exposure to light, and which can produce hydroperoxides [4-6]. Although these are relatively stable species, trace amounts of transitional metals such as iron or copper (e.g., from stainless steel or metal affinity chromatography) can catalyse the 
conversion of these species into potent oxidants (e.g., hydroxyl radicals) [7-10]. Indeed, there are numerous studies on the metal-catalysed oxidation of proteins in the literature [11-13].

Zhou et al. studied the two metal chelators disodium ethylenediaminetetraacetic acid $\left(\mathrm{Na}_{2} \mathrm{EDTA}\right)$ and diethylenetriaminepentaacetic acid (DTPA) to define their stabilisation of a monoclonal antibody in solution formulations spiked with $\mathrm{Fe}(\mathrm{II})$. When the ratio of chelator to iron ions was $>1$, both $\mathrm{Na}_{2}$ EDTA and DTPA reduced protein degradation. Under conditions of metal-catalysed oxidation, the incorporation of such chelating agents might reduce the rate of oxidation of proteins by scavenging the free metal ions before they oxidise the proteins [14]. Additionally, mannitol and EDTA are effective against $\mathrm{H}_{2} \mathrm{O}_{2}$ - and $\mathrm{Fe}(\mathrm{II})$-induced oxidation of proteins in solution [15].

However, it is not valid to assume that the addition of a chelating agent will eliminate oxidation, particularly if iron is the catalytic species. Kachur et al. reported that metal chelators such as EDTA and DTPA accelerated production of hydroxyl radicals $\left({ }^{\bullet} \mathrm{OH}\right)$ during autooxidation of ferrous ion (Fe(III)) complexes. If the $\mathrm{Fe}(\mathrm{III})$ complex is reduced to $\mathrm{Fe}(\mathrm{II})$ when oxygen is present, this results in the production of ${ }^{\bullet} \mathrm{OH}$. This enhancement of autooxidation after chelation of iron was explained by alteration of the reaction mechanism from two-electron to one-electron reduction of oxygen molecules. The maximal yield of ${ }^{\bullet} \mathrm{OH}$ was seen with equal concentrations of chelator and $\mathrm{Fe}(\mathrm{II})[16,17]$.

Kocha et al. studied $\mathrm{H}_{2} \mathrm{O}_{2}$-mediated degradation of albumin. After exposure of albumin to the Fenton reaction between $\mathrm{H}_{2} \mathrm{O}_{2}$ and $\mathrm{Fe}(\mathrm{II}) /(\mathrm{III})$, little ${ }^{\bullet} \mathrm{OH}$ was produced, and this was markedly increased by addition of EDTA [18]. Similarly, Fransson showed that oxidation of methionine only occurred with Fe(III) when EDTA was also added [19].

The presence of oxygen is a necessary condition for protein oxidation. This oxygen can be reduced to the superoxide radical, and subsequently to $\mathrm{H}_{2} \mathrm{O}_{2}$, which is relatively stable (Figure 1). $\mathrm{H}_{2} \mathrm{O}_{2}$ can then be converted by the catalytic action of $\mathrm{Cu}(\mathrm{I})$ or $\mathrm{Fe}(\mathrm{II})$ to ${ }^{\bullet} \mathrm{OH}$ (Figure 1), which can then oxidise, and thus damage, amino acids in proteins. The influence of iron or copper chelation on the production of - $\mathrm{OH}$ from $\mathrm{H}_{2} \mathrm{O}_{2}$ (i.e., the Fenton reaction) can be studied using an ascorbate redox system assay. In this assay, the ascorbate promotes reduction of $\mathrm{Fe}(\mathrm{III})$ to $\mathrm{Fe}(\mathrm{II})$, to maintain the $\mathrm{Fe}(\mathrm{II})$ levels. The $\mathrm{Fe}(\mathrm{II})$ can initially reduce oxygen to the superoxide radical. Subsequently, the $\mathrm{Fe}(\mathrm{II})$ reduces this to $\mathrm{H}_{2} \mathrm{O}_{2}$, and then finally converts $\mathrm{H}_{2} \mathrm{O}_{2}$ to the hydroxyl radical via the Fenton reaction (Figure 1) [20-22].

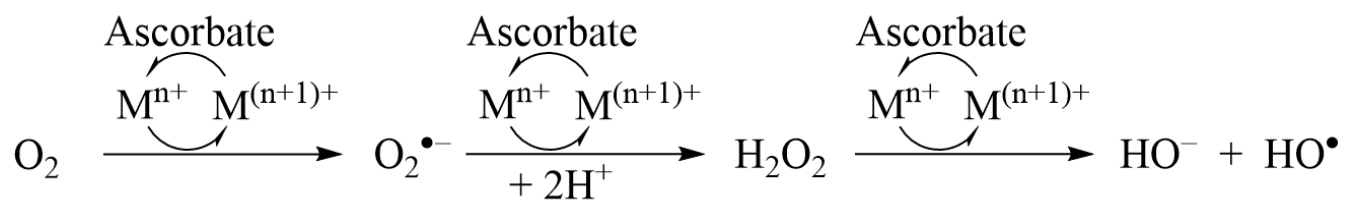

Figure 1. Metal-catalysed generation of reactive oxygen species $\left(\mathrm{M}^{\mathrm{n}+}: \mathrm{Cu}(\mathrm{I})\right.$ or $\left.\mathrm{Fe}(\mathrm{II})\right)$.

Unlike this ascorbate test system, the iron or copper in biopharmaceutical formulations can be reduced by, e.g., $\mathrm{H}_{2} \mathrm{O}_{2}$ or hydroperoxides that are introduced with the excipients $[4,18]$. Therefore, formulators tend to add chelators as a precautionary measure when oxidation of proteins is detected, such as EDTA or DTPA. However, previous studies on the influence of such chelating agents on the stability of pharmaceutical formulations have not been consistent as to whether EDTA and DTPA enhance or inhibit the Fenton reaction, and thus further studies are needed to clarify this.

Deleterious effects of reactive oxygen species do not end with protein and excipient oxidation. These oxidation products can react with the protein and impact upon its stability, and any resulting adducts can induce unwanted immune responses $[23,24]$. This is particularly relevant to the oxidation of polysorbates. These represent one of the most commonly used excipients in such biopharmaceutical formulations, which can result in the production of an array of potentially damaging products [25-29]. $\mathrm{Ha}$ et al. reported that polysorbate 80 (PS80) can increase oxidation products in an interleukin-2 formulation. This higher level of peroxides produced resulted in significant increases in oxidation in both the liquid and solid states. They also demonstrated that peroxides can be generated in pure PS80 in the presence of air at elevated temperatures [4]. Similarly, Knepp et al. demonstrated that alkyl 
hydroperoxides in PS80 can induce oxidation, dimerisation and subsequent aggregation of recombinant human ciliary neurotrophic factor [30].

Unlike oxidation of proteins, which is generally a one-off event in the absence of further production of reactive oxygen species, the oxidation of unsaturated fatty-acid esters of polysorbates can trigger lipid peroxidation, which is a cyclic process that can self-propagate. In particular, PS80 that contains higher levels of polyunsaturated fatty-acid esters is more prone to lipid peroxidation [31-33]. Many different chemical species can be produced as a result of polysorbates oxidation, including aldehydes, ketones and peroxides $[27,28]$. Detection of the production of such oxidation products is often problematic without their chemical derivatisation. Low molecular weight aldehydes and ketones show low ionisation efficiencies in mass spectrometry (MS) analysis due to their low proton affinities. Therefore, their chemical derivatisation is usually carried out with hydrazides, hydrazines, hydroxylamines or coumarines [29,34,35].

In the present study, we investigated the influence of metal ions, chelating agents and antioxidants on the rate of the Fenton reaction in a formulation of a therapeutic protein using the ascorbate redox system assay. Damage to the protein by reactive oxygen species was investigated using peptide mapping. Furthermore, the products of oxidative degradation of the polysorbate were derivatised and analysed using ultrahigh performance liquid chromatography with high-resolution MS (UHPLC-HRMS).

\section{Materials and Methods}

\subsection{Solvents and Reagents}

DTPA, EDTA, glutathione (GSH), quercetin, coumarine-3-carboxylic acid (CCA), 7-(diethylamino)coumarin-3-carbohydrazide $(\mathrm{CHH})$, desferrioxamine, ascorbate, potassium phosphate $\left(\mathrm{KH}_{2} \mathrm{PO}_{4}\right)$, and multi-compendial grade polysorbate 20 (PS20) and PS80 were from Sigma-Aldrich (Merck KgaA, Darmstadt, Germany). Copper(II) chloride and iron(III) chloride were from Acros Organics (Thermo Fischer Scientifics, Waltham, MA, USA). Ultra-gradient HPLC grade acetonitrile was from J.T. Baker (Avantor Performance Materials, Radnor, PA, USA). Liquid chromatography-MS grade methanol was from Merck KgaA (Darmstadt, Germany). Ultrapure water was from a Millipore Milli-Q water system (Merck KgaA, Darmstadt, Germany). The therapeutic protein solution was provided by Lek d.d. (Mengeš, Slovenia).

\subsection{Ascorbate Redox System Assay}

The promotion of ${ }^{\bullet} \mathrm{OH}$ production by chelating agents and antioxidants was evaluated in an ascorbate redox system assay, as described previously [20,36-39]. The Fe(III) chloride and $\mathrm{Cu}$ (II) chloride were dissolved and diluted in ultrapure water. All of the other solutions were prepared in $20 \mathrm{mM} \mathrm{KH}{ }_{2} \mathrm{PO}_{4}$ buffer, $\mathrm{pH}$ 7.4. Each experiment was performed in triplicate using flat-bottomed 96-well black microtitre plates (Greiner Bio-One, Frickenhausen, Germany). For the hydroxyl radical, - $\mathrm{OH}$ production was measured as the conversion of CCA into 7-hydroxy-CCA ( $\lambda_{\text {excitation }}, 395 \mathrm{~nm}$; $\lambda_{\text {emission, }} 450 \mathrm{~nm}$ ). The general order of addition was as follows (in brackets are final concentrations): CCA $(100 \mu \mathrm{M})$; chelating agent or antioxidant (EDTA, DTPA; GSH, quercetin) $(10 \mu \mathrm{M}) ; \mathrm{Cu}(\mathrm{II})(10 \mu \mathrm{M})$ or Fe(III) $(10 \mu \mathrm{M})$; and then following a 30 min incubation, ascorbate $(300 \mu \mathrm{M})$. In selected samples, protein solution $(250 \mu \mathrm{g} / \mathrm{mL})$ or polysorbate solution $(10 \mu \mathrm{g} / \mathrm{mL})$ was added, and consequently the CCA volume was reduced (while maintaining the final incubation concentration). All of the test solutions also contained $1 \mu \mathrm{M}$ desferrioxamine.

\subsection{Peptide Mapping}

Endoproteinase Lys-C was used as the proteolytic enzyme for digestion of the therapeutic protein. The resulting peptides were separated from the parent peptide using reverse-phase liquid chromatography. Quantification of relative amounts of oxidised methionine generated was through UV chromatography. The oxidative activities are expressed as the area under the chromatographic peak 
of the modified methionine produced relative to the sum of the areas under the total chromatographic peaks corresponding to the therapeutic peptide in each sample (i.e., modified plus unmodified). Chromatographic analysis was carried out using the method developed by Griffiths et al. [40].

The experimental additions to the therapeutic protein solution in these incubations thus included (in brackets are final concentrations): no further additions (control); Fe(III) $(0.1 \mathrm{mM})$ without and with ascorbate $(3 \mathrm{mM}) ; \mathrm{Fe}(\mathrm{III})(0.1 \mathrm{mM})$ and EDTA $(0.1 \mathrm{mM})$ without and with ascorbate $(3 \mathrm{mM})$. All of the stock solutions were prepared in Tris/ $\mathrm{HCl}$ buffer, except for the Fe(III) (ultrapure water). All samples were incubated at $37^{\circ} \mathrm{C}$ for $42 \mathrm{~h}$.

\subsection{Oxidation of Polysorbates}

Polysorbates PS20 and PS80 (10 mmol/L) were incubated in a mixture of ethanol and water (10:90; $v / v)$ containing $0.5 \mathrm{mmol} / \mathrm{L}$ copper(II) sulphate and $1 \mathrm{mmol} / \mathrm{L}$ ascorbate at $37^{\circ} \mathrm{C}$ on an orbital shaker for $72 \mathrm{~h}$. After this oxidation, the low and high molecular weight carbonylated compounds produced were derivatised with $\mathrm{CHH}$ and analysed immediately by direct injection into the high-resolution positive electrospray ionisation-MS, as described by Milic et al. [35]. Moreover, the compositions of the non-derivatised oxidised polysorbate samples were analysed using UHPLC-HRMS.

\subsection{Polysorbate Composition Profile}

Mass spectrometry ( $Q$ Exactive Plus Hybrid Quadrupole-Orbitrap mass spectrometer; Thermo Fischer Scientific Inc., Waltham, MA, USA) was performed under the following basic MS parameters: sheath gas flow rate, 25 (arbitrary units); auxiliary gas flow rate, 10 (arbitrary units); capillary temperature, $350^{\circ} \mathrm{C}$; and spray voltage, $3.5 \mathrm{kV}$. The MS was operated in positive electrospray ionisation. The compounds were analysed using a C18 reversed-phase column (Poroshell 300SB; $5 \mu \mathrm{m}$ particle size; $2.1 \mathrm{~mm} \times 75 \mathrm{~mm}$; Agilent, Santa Clara, CA, USA) at a column temperature of $30{ }^{\circ} \mathrm{C}$ and a flow rate of $0.7 \mathrm{~mL} / \mathrm{min}$. The injection volume was $5 \mu \mathrm{L}$, with a total run time of $45 \mathrm{~min}$. Chromatographic analysis was based on the modified method of Fekete et al. [41].

\section{Results and Discussion}

\subsection{Ascorbate Redox System Assay}

First, the production of ${ }^{\bullet} \mathrm{OH}$ during autooxidation of $\mathrm{Fe}(\mathrm{III})$ and $\mathrm{Cu}(\mathrm{II})$ complexes was investigated in the ascorbate redox system assay in the absence and presence of different chelating agents (i.e., EDTA, DTPA) and antioxidants (i.e., GSH, quercetin) (Figures 2 and 3; Figures S1 and S2). Furthermore, the addition of protein under the same $\mathrm{Fe}(\mathrm{III})$ and $\mathrm{Cu}$ (II) conditions was evaluated (Figures 2 and 3; Figures S3 and S4), as well as the impact of PS80 addition under these Fe(III) conditions (Figure 2; Figure S5).

Production of $\bullet \mathrm{OH}$ in the presence of Fe(III) ions was strongly accelerated only by addition of EDTA, while addition of DTPA (Figure 2) or antioxidants (Figure S1) to the ascorbate assay showed similar responses to the negative controls. This appears to occur through iron cycling via iron complexation (Figure 1). In the presence of protein, the production of ${ }^{\bullet} \mathrm{OH}$ was less pronounced, which will be due to the competition of the protein with CCA for ${ }^{\bullet} \mathrm{OH}$. In the absence of EDTA, the reaction was slower or inhibited fully. Similar to the presence of protein, PS80 addition also resulted in lower ${ }^{\bullet} \mathrm{OH}$ production, as PS80 is highly susceptible to radical attack, and will therefore compete with CCA for ${ }^{\bullet} \mathrm{OH}$. PS80 contains saturated and unsaturated fatty acids, and its free-radical-initiated mechanism is well established, which consists of the chain initiation, propagation and termination steps. In order to compare the results more easily, initial reaction rates have been calculated (Table S1). 
A

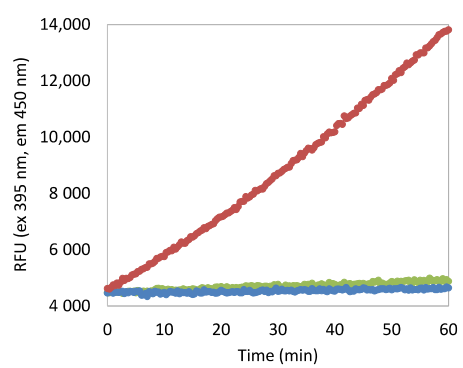

C

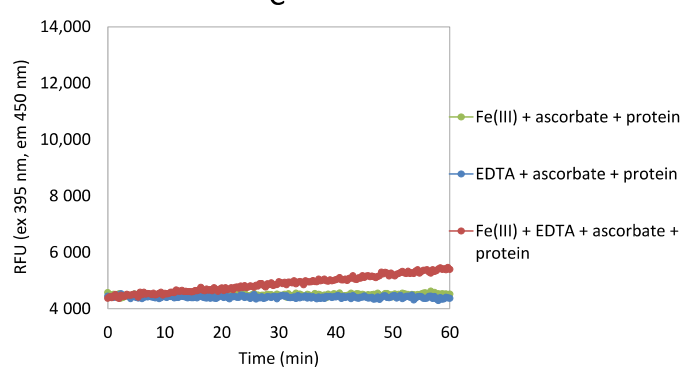

$\mathrm{E}$

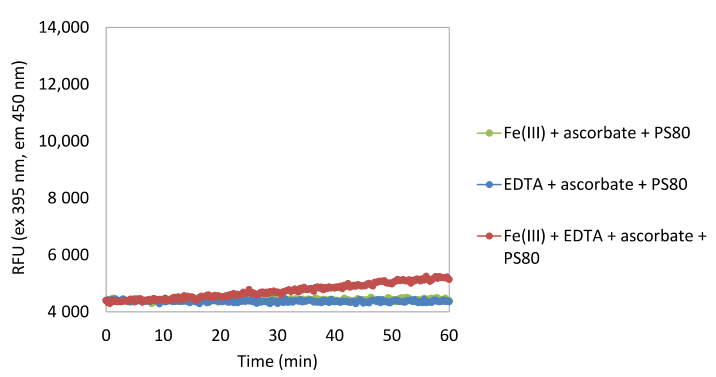

B

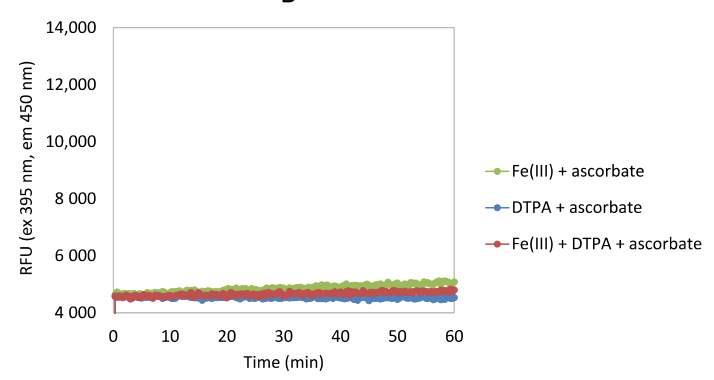

D

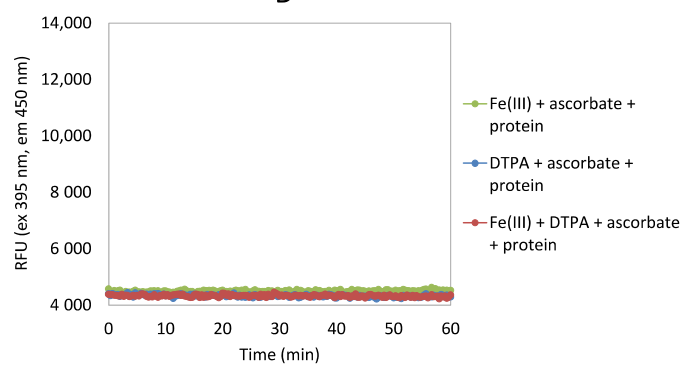

$\mathrm{F}$

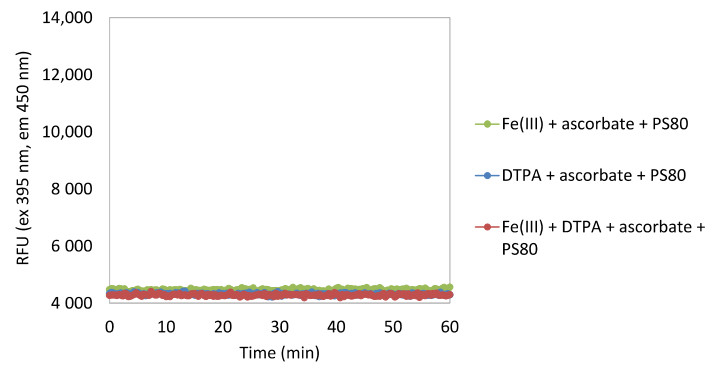

Figure 2. Time courses of the production of $\bullet \mathrm{OH}$ (RFU, relative fluorescence units) during autooxidation of $\mathrm{Fe}(\mathrm{III})$ complexes measured according to the fluorescence intensities of 7-hydroxy-coumarine-3-carboxylic acid after incubations of CCA with ascorbate $\pm \mathrm{Fe}(\mathrm{III})$, and \pm ethylenediaminetetraacetic acid (EDTA) $(\mathrm{A}, \mathrm{C}, \mathrm{E})$ or \pm diethylenetriaminepentaacetic acid (DTPA) (B,D,F), and plus protein (C,D) or plus PS80 (E,F). Positive control, ascorbate and Fe(III), and plus protein (C,D) or plus PS80 (E,F); negative control, ascorbate plus chelating agent (EDTA/DTPA) or antioxidant (quercetin/GSH), and plus protein (C,D) or plus PS80 (E,F); see also Figures S1, S3 and S5. All solutions were prepared in $20 \mathrm{mM} \mathrm{KH}_{2} \mathrm{PO}_{4}, 1 \mu \mathrm{M}$ desferrioxamine, $\mathrm{pH}$ 7.4, except $\mathrm{FeCl}_{3}$ (ultrapure water).

In contrast to the use of $\mathrm{Fe}(\mathrm{III})$ ions in the ascorbate assay, $\mathrm{Cu}$ (II) ions have greater reactivity and accelerated the reaction also in the absence of the chelators EDTA and DTPA (Figure 3). Interestingly, the addition of EDTA in combination with $\mathrm{Cu}(\mathrm{II})$ completely inhibited ${ }^{\bullet} \mathrm{OH}$ production. Addition of DTPA here showed some inhibition of ${ }^{\bullet} \mathrm{OH}$ production, although this remained greater compared to EDTA. Addition of the reducing reagents quercetin and GSH had no impacts on the $\mathrm{Cu}(\mathrm{II})$-induced autooxidation here, with similar responses to the positive control (Figure S2). As already shown for $\mathrm{Fe}(\mathrm{III})$, the addition of protein lowered the production of ${ }^{\bullet} \mathrm{OH}$ in $\mathrm{Cu}(\mathrm{II})$, which was completely inhibited here by the addition of either EDTA or DTPA with the protein (Figure 3).

According to the data obtained here, as well as the concentration of the complex, the rate of generation of ${ }^{\bullet} \mathrm{OH}$ strongly depends on the metal ion and the chelator used. Comparing Fe(III) and $\mathrm{Cu}(\mathrm{II})$, the efficiency of EDTA and DTPA to accelerate the Fenton reaction for the production of ${ }^{\bullet} \mathrm{OH}$ was not equivalent. With Fe(III), EDTA strongly accelerated ${ }^{\bullet} \mathrm{OH}$ production, whereas DTPA slowed it with both $\mathrm{Fe}(\mathrm{III})$ and $\mathrm{Cu}(\mathrm{II})$. With the addition of protein or PS80, the production of ${ }^{\bullet} \mathrm{OH}$ has been less pronounced because the protein/PS80 will have competed with CCA for ${ }^{\bullet} \mathrm{OH}$. The main advantage of 
ascorbate redox system assay is the simplicity of the test, rapid results and small amount of sample needed. However, the change in the rate of CCA production does not provide any solid information about the underlaying mechanism. For a more detailed interpretation of the ascorbate redox system assay, a method with higher specificity should be used (e.g., peptide mapping).

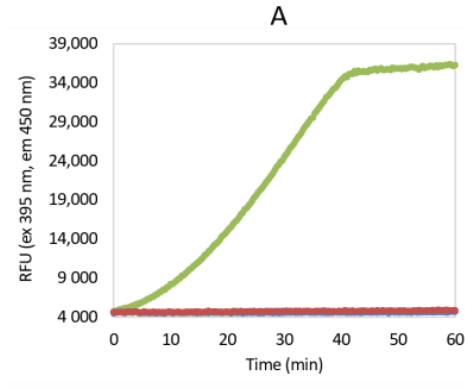

C

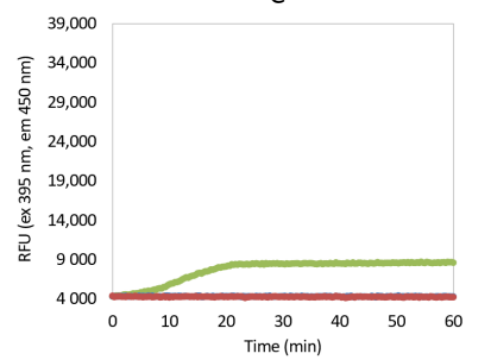

- Cu(II) + ascorbate -EDTA + ascorbate $\rightarrow-\mathrm{Cu}(11)+$ EDTA + ascorbate

$\rightarrow-\mathrm{Cu}(I I)+$ ascorbate + protein -EDTA + ascorbate + protein $\rightarrow-\mathrm{Cu}(I I)+$ EDTA + ascorbate + protein

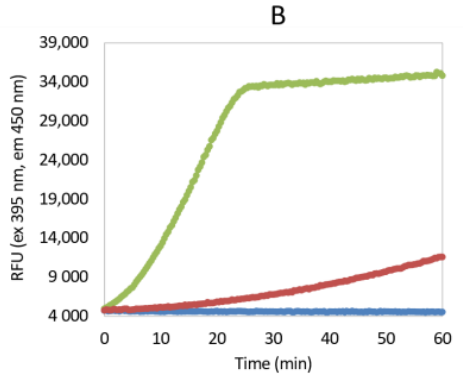

D

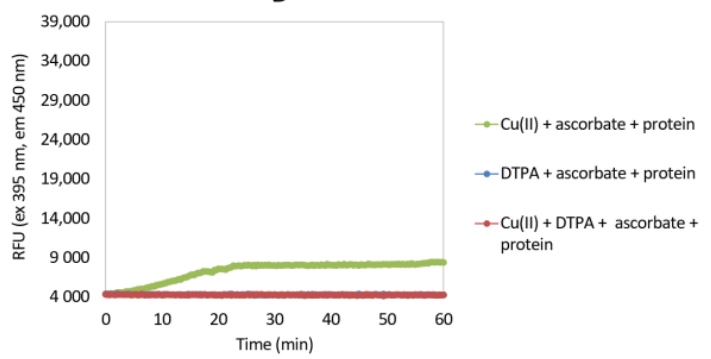

Figure 3. Time courses of the production of $\bullet \mathrm{OH}$ (RFU, relative fluorescence units) during autooxidation of $\mathrm{Cu}(\mathrm{II})$ complexes measured according to the fluorescence intensity of 7-hydroxy-coumarine-3-carboxylic acid after incubation of CCA with ascorbate $\pm \mathrm{Cu}$ (II), and \pm EDTA $(\mathbf{A}, \mathbf{C})$ or \pm DTPA $(\mathbf{B}, \mathbf{D})$, and plus protein $(\mathbf{C}, \mathbf{D})$. Positive control, ascorbate plus $\mathrm{Cu}(\mathrm{II})$, and plus protein (C,D); negative control, ascorbate plus chelating agent (EDTA/DTPA) or antioxidant (quercetin/GSH), and plus protein (C,D); see also Figures S2 and S4. All solutions were prepared in $20 \mathrm{mM} \mathrm{KH}_{2} \mathrm{PO}_{4}$, $1 \mu \mathrm{M}$ desferrioxamine, $\mathrm{pH} 7.4$, except $\mathrm{CuCl}_{2}$ (ultrapure water).

\subsection{Peptide Mapping}

Peptide mapping is a technique for the identification and characterisation of proteins and their modifications. Peptide mapping methods have been specifically developed to locate protein regions (i.e., amino acids) that have been altered (e.g., oxidised). It is well known that the susceptibility to oxidation of methionine residues depends on their location within the structure of a protein. Oxidation of methionine side chains can be mediated by double electron transfer (e.g., by non-radical oxidants, such as peroxides) or single electron transfer (e.g., by metal catalysis) [42], although here we focussed only on single electron transfer with iron.

Most chelators result in equimolar complexes with iron [16]. Zhou et al. showed that EDTA and DTPA cannot protect the degradation of a protein by iron if the ratio of the molar concentrations of the metal chelator to iron is less than 1:1 (i.e., an excess of chelator is required) [14]. Therefore, in the present study, equal concentrations of iron and chelator were used for the oxidation, although with a 30-fold excess of ascorbate over iron, to ensure that most of the iron was in the ferrous (Fe(II)) form.

Using peptide mapping, we resolved the oxidised peptides from those that were not oxidised (Figure 4). Moreover, we measured protein oxidation under the various stress conditions. The optimum choice of chemical additives needs to be evaluated on the basis of the specific protein oxidation mechanism. The different conditions investigated to induce oxidation of methionine in the protein solution were thus: without additives (control), Fe(III) without and with ascorbate, Fe(III) and EDTA without and with ascorbate. 


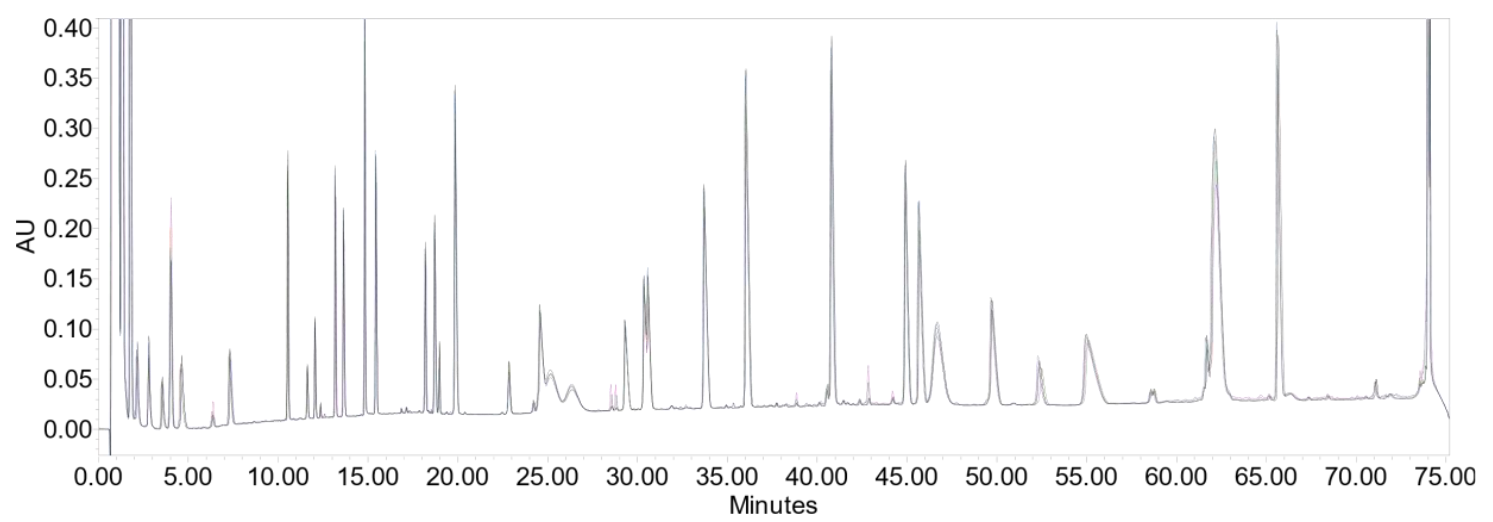

Figure 4. HPLC-UV peptide map of the therapeutic protein. Fragments were prepared by protein digestion, as described in the Materials and Methods Section.

These data showed that Fe(III) or EDTA alone did not trigger the oxidation, and that there is the need to include a reducing agent (e.g., ascorbate) and a chelating agent (e.g., EDTA) for high levels of oxidation (Figure 5; Table 1).

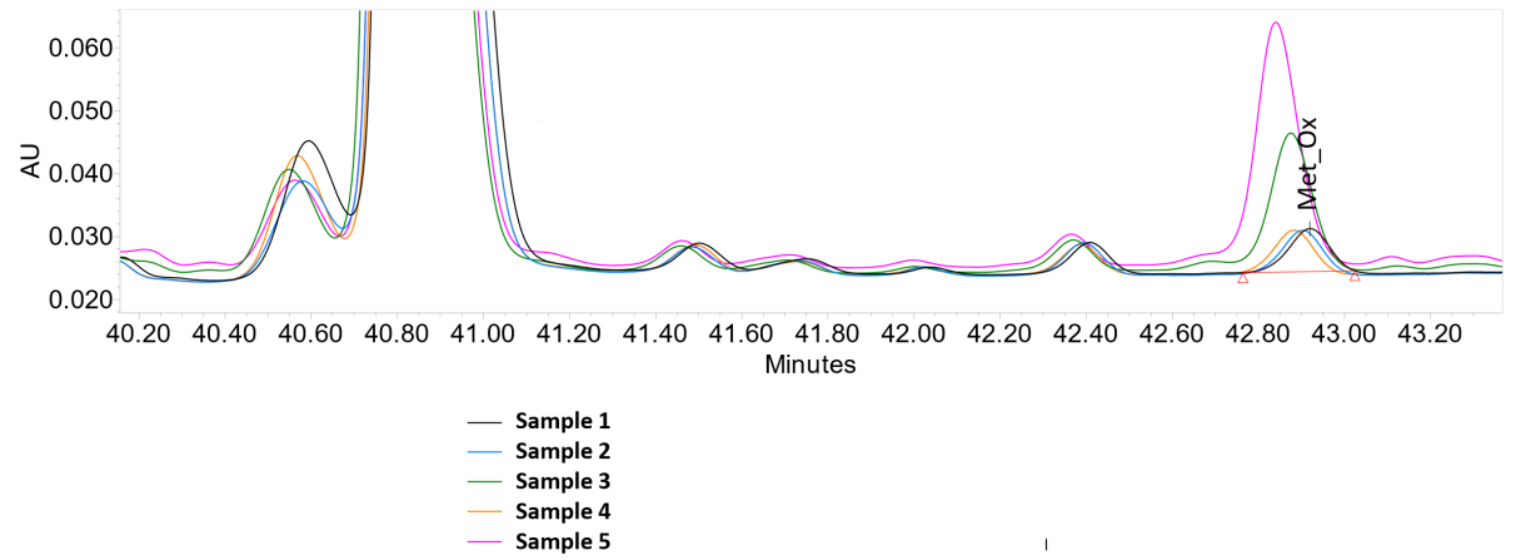

Figure 5. HPLC-UV peptide map of the degraded and non-degraded protein considering the oxidised methionine peaks indicated (Met_ox). The five experimental conditions ('sample names') are as indicated in Table 1.

Table 1. Peptide mapping analysis for the methionine oxidation, as determined by HPLC-UV (e.g., Figure 5).

\begin{tabular}{ccc}
\hline Sample & Composition & Met_Ox \\
\hline 1 & control sample (without additives) & 1.8 \\
2 & Fe(III) & 1.7 \\
3 & Fe(III) + ascorbate & 6.4 \\
4 & Fe(III) + EDTA & 1.8 \\
5 & Fe(III) + EDTA + ascorbate & 12.9 \\
\hline
\end{tabular}

As reported previously, methionine oxidation (Figure 6) in protein biopharmaceuticals has been correlated with number of adverse effects, whereby the therapeutic protein can undergo a loss of function, loss of activity and/or increase in aggregation propensity. These processes, therefore, need to be carefully controlled $[43,44]$. During the protein processing and storage, the levels of transition metals should be monitored and the addition of chelating agents should be considered. Additionally, EDTA can facilitate migration of metal ions from metal contact surfaces into solution, as reported by Kocijan et al. [45] and Zhou et. al. [46]. This can thus be important for the stability of a therapeutic 
protein, as we have shown here that addition of EDTA can enhance its oxidative degradation. Therefore, the addition of chelating agents to the therapeutic protein formulation should be carefully considered and the final decision supported by experimental data.

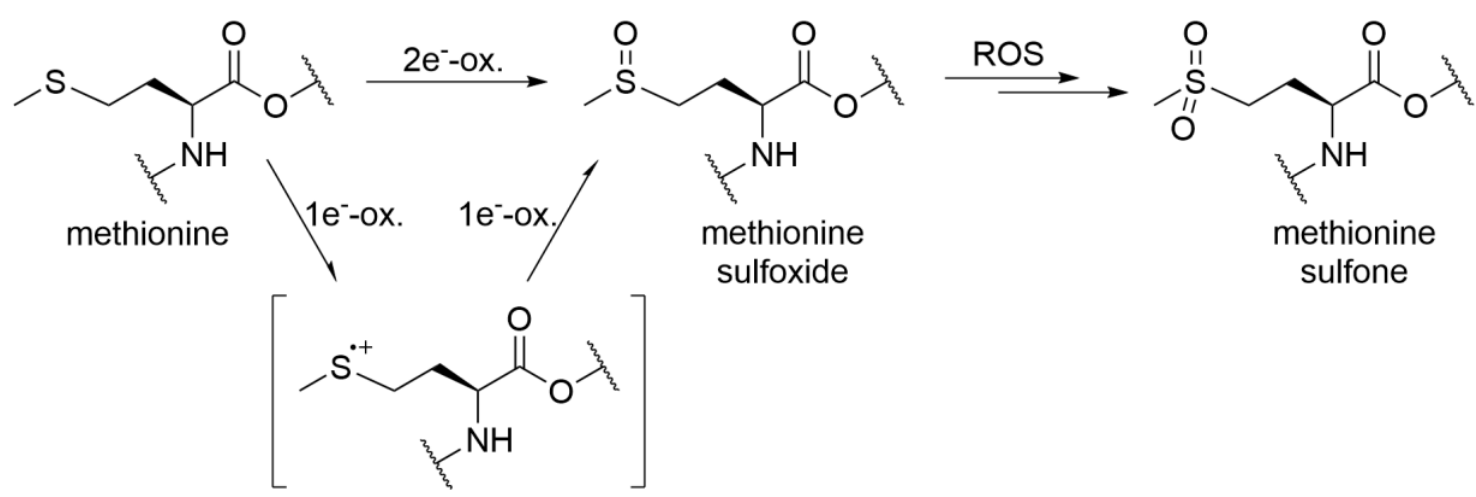

Figure 6. Pathways of methionine oxidation.

\subsection{Polysorbates Degradation: Oxidation of Polysorbates and Their Composition Profiles}

The stabilising properties of polysorbates in solution can be overshadowed by their susceptibility to autooxidation. The major sites for initiation of autooxidation for polysorbates include unesterified polyoxyethylenes [25], ester bonds [47] and the unsaturation sites of fatty acids [32,48]. Polysorbates are mixtures of various fatty acid esters. The main fatty acid of the multi-compendial grade PS20 is lauric acid (C12:0), which represents $40 \%$ to $60 \%$ of the total number of free fatty acid species, whereas in PS80 it is predominantly oleic acid (C18:1) with $\geq 58 \%$. Besides, high levels of monounsaturated oleic acid and also relatively high levels of long-chain polyunsaturated fatty acids are presented in multi-compendial PS80, such as linoleic acid (C18:2; $\leq 18 \%)$ and linolenic acid (C18:3; $\leq 4 \%)$ [49].

Due to the larger number of oxidisable sites in the fatty-acid chains of PS80 versus PS20, PS80-containing formulations are known to be more susceptible to oxidative degradation than PS20 formulations [4,27]. Moreover, lower levels of polyunsaturated fatty acids contribute less to oxidative degradation than higher levels monounsaturated oleic acid [50]. In contrast to PS80, the $\alpha$-carbons of polyoxyethylenes are the most susceptible for oxidation in PS20 [25,48].

We also studied here the influence of $\mathrm{Cu}$ (II) ions and ascorbate on the oxidation of the PS20 and PS80 polysorbates. After oxidation, the samples were derivatised with $\mathrm{CHH}$ for the MS analysis (Figures 7 and 8). According to the data from the ascorbate redox assays, oxidation with $\mathrm{Cu}$ (II) was faster compared to that for Fe(III). Moreover, there was no need to accelerate the copper redox cycling by metal complexation. The method was developed according to the lipid peroxidation method of Milic et al. [35], who studied polyunsaturated fatty acids in lipids. This was thus successfully adopted to testing the stability of polysorbates here for the first time, and this might prove to be very useful in the future for monitoring oxidative degradation of polysorbates.

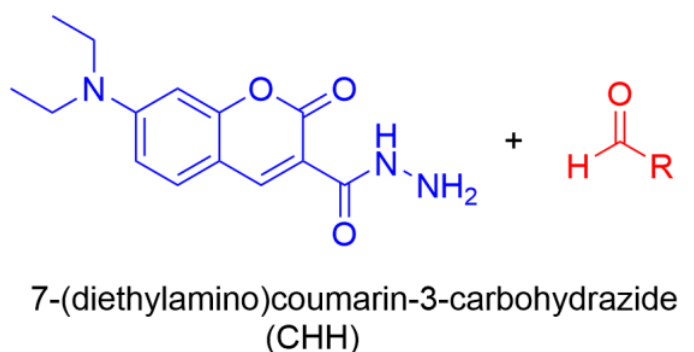<smiles>COCO</smiles>
$(\mathrm{CHH})$<smiles>[R]C=NNC(=O)c1cc2ccc(N(CC)CC)cc2oc1=O</smiles>

Hydrazone

Figure 7. Derivatization reaction of oxidation products of polysorbate with $\mathrm{CHH}$. 
<smiles>C=NNC(=O)c1cc2ccc(N(CC)CC)cc2oc1=O</smiles><smiles>C/C=C/C(=O)N/N=C/CC</smiles><smiles>CCN(CC)c1ccc2cc(C(=O)NN=CC=NNC(=O)c3cc4ccc(N(CC)CC)cc4oc3=O)c(=O)oc2c1</smiles><smiles>CCC/C=N/NC(=O)c1cc2ccc(N(CC)CC)cc2oc1=O</smiles>

\section{Ethandial}

Butanal

Figure 8. The most common oxidation products identified here from PS20 and PS80 after derivatisation with $\mathrm{CHH}$. The additional oxidation products identified are shown in Figures S6 (PS20) and S7 (PS80).

For PS20, 18 oxidation products were identified here (Figure 8; Figure S6), with more than twice $(n=39)$ identified from PS80 (Figure 8; Figure S7). Indeed, PS80 contains higher levels of long-chain fatty-acid esters compared to PS20, and it is therefore more prone to oxidation. As expected, the greater the number of double bounds in the polysorbates, the higher their susceptibility to oxidation.

Cleavage of the oleic acid double bond mainly produced low-molecular-weight aldehydes $(\leq \mathrm{C} 8)$, which are also more reactive than long-chain aldehydes. Additionally, during the polysorbates degradation, the oxidation products might themselves induce direct changes in the protein structure, which can result in less protein stabilisation.

With the higher content of different fatty acids in PS20 compared to PS80, the profile of the PS20 composition from the chromatograms was more complex. Using reverse-phase chromatography, the subspecies in the non-degraded and degraded PS20 were separated and eluted, as shown in Figure 9. After the oxidation of PS20 (Figure 9, bottom), all of the major peaks were absent. Monoesters with lauric acid were the most abundant in the non-degraded PS20 (Figure 9, top), whereas in the degraded PS20, aside from the most abundant non-esterified species, only low levels of mono- and diesters with lauric, palmitic and oleic acid remained (Figure 9, bottom).

Again, using reverse-phase chromatography, the subspecies in the non-degraded and degraded PS80 were eluted and identified, as shown in Figure 10. For the non-degraded PS80, the monoesters were the most abundant, followed by the diesters and then the triesters (Figure 10, top). In contrast, in the degraded PS80, the non-esterified species were the most abundant, while the proportions of monoesters and polyesters were greatly lowered, and the triesters were completely degraded (Figure 10, bottom). The whole chromatogram was also slightly shifted for the degraded PS80. 


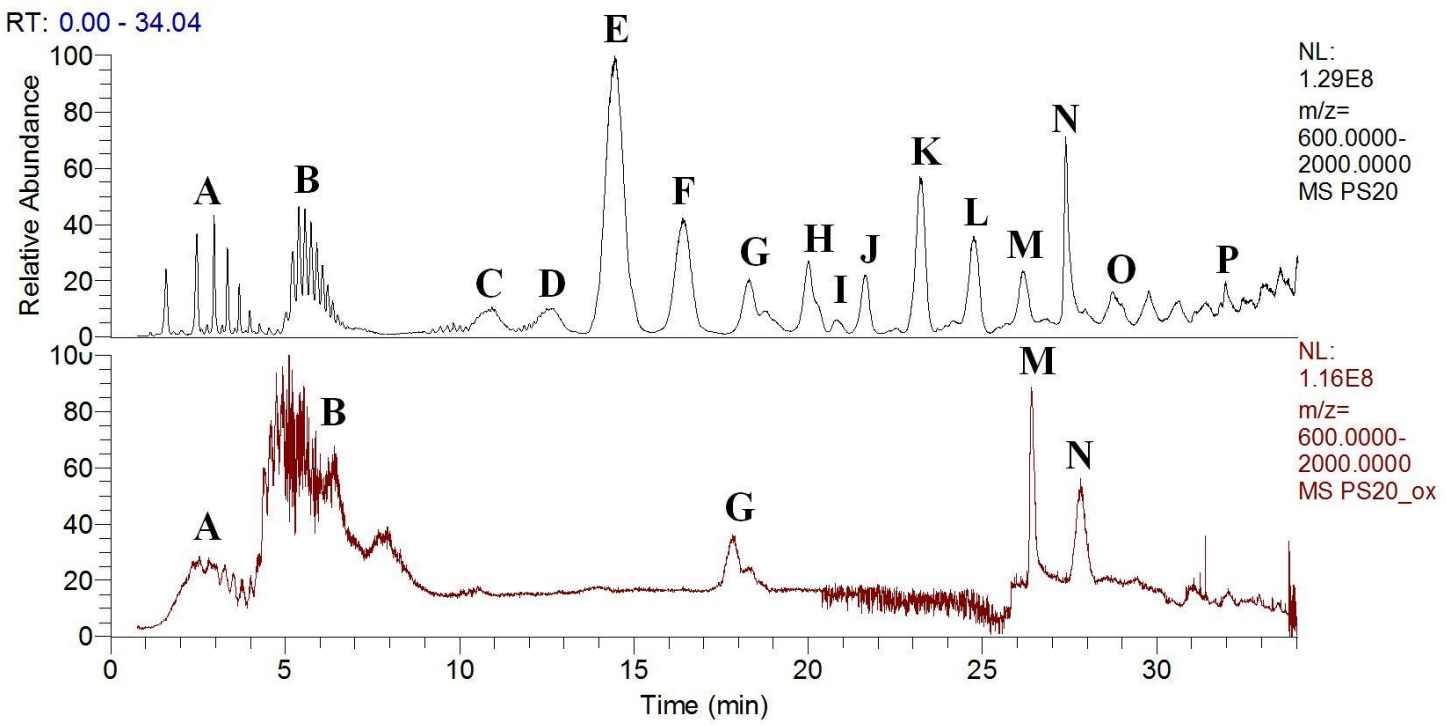

Figure 9. Total ion current ( $\mathrm{Mr} \geq 600 \mathrm{Da}$ ) chromatograms of non-degraded (top) and degraded (bottom) PS20 after oxidation with $\mathrm{Cu}(\mathrm{II})$ and ascorbate, and following UHPLC-HRMS. The subspecies in the non-degraded PS20 were identified as: A, unesterified polyoxyethylene isosorbides; $\mathbf{B}$, unesterified polyoxyethylene sorbitans; C, monoesters with caprylic acid; D, monoesters with capric acid; E, monoesters with lauric acid; F, monoesters with myristic acid; G, monoesters with palmitic acid; H, monoesters with oleic acid; I, diesters with lauric and caprylic acid; J, diesters with lauric and capric acid; K, diesters with double lauric acid; $\mathbf{L}$, diesters with lauric and myristic acid; $\mathbf{M}$, diesters with lauric and palmitic acid; $\mathbf{N}$, diesters with lauric and oleic acid; $\mathbf{O}$, triesters of polyoxyethylene sorbitan; $\mathbf{P}$, tetraesters of polyoxyethylene sorbitan.

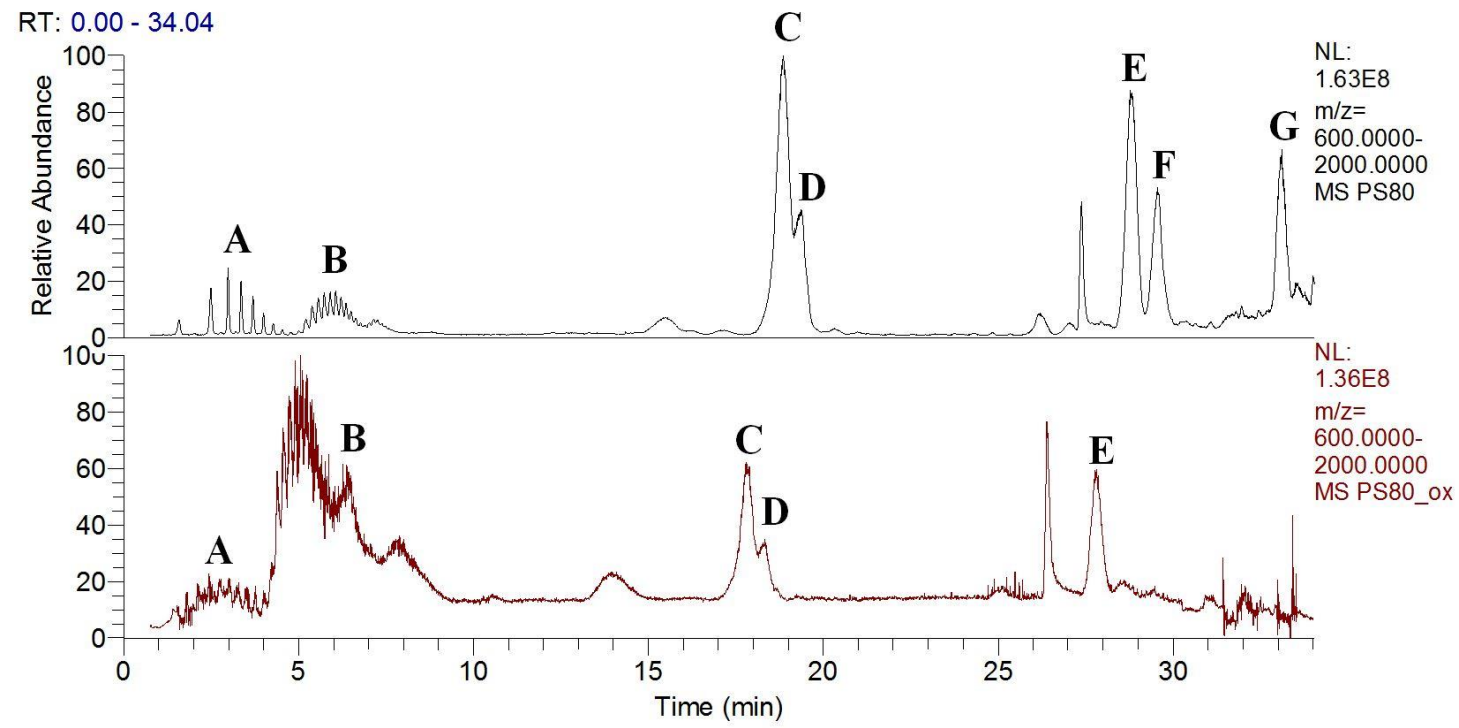

Figure 10. Total ion current ( $\mathrm{Mr} \geq 600 \mathrm{Da})$ chromatograms of non-degraded top) and degraded (bottom) PS80 after oxidation with $\mathrm{Cu}(\mathrm{II})$ and ascorbate, and following UHPLC-HRMS. The subspecies in the non-degraded PS80 were identified as: A, unesterified polyoxyethylene isosorbides, unesterified polyoxyethylenes; B, unesterified polyoxyethylene sorbitans; C, monoesters of polyoxyethylene sorbitan, polyoxyethylene monoesters; D, monoesters of polyoxyethylene isosorbide; E, diesters of polyoxyethylene sorbitan; F, diesters of polyoxyethylene isosorbide; $G$, triesters of polyoxyethylene sorbitan. 


\section{Conclusions}

To avoid stability problems for protein solutions containing polysorbates, the levels of transition metals should be carefully controlled during protein processing and storage, and the addition of chelating agents can be considered. According to the data from the present study, it is not valid to assume that the addition of chelators will eliminate protein oxidation, particularly if iron, rather than copper, is the contaminating metal. The oxidation of methionine was catalysed by dissolved oxygen, Fe(III) and ascorbate, and this was accelerated on addition of EDTA. As for protein solutions, metal ions in combination with ascorbate can also be problematic for polysorbate solutions. Any addition of chelating agents to the therapeutic protein formulations should be based on experimental data confirming the beneficial effect of such an addition. Using UHPLC-HRMS, we defined and compared the composition profiles of the non-degraded and degraded PS20 and PS80 polysorbates, with the various degradation products of this metal-catalysed oxidation identified. This method developed here for polysorbates derivatisation should be of great use in future stability studies for the monitoring of polysorbates oxidation.

Supplementary Materials: The following are available online at http://www.mdpi.com/2076-3921/9/5/441/s1.

Author Contributions: Conceptualisation, E.V.B., S.P., R.Š., J.M.; methodology, E.V.B.; writing—original draft preparation, E.V.B., S.P., R.Š., J.M.; writing-review and editing, E.V.B., S.P., R.Š., J.M.; visualisation, E.V.B., S.P., R.S., J.M.; supervision, S.P., J.M. All authors have read and agreed to the published version of the manuscript.

Funding: This research received no external funding.

Acknowledgments: The authors acknowledge the support from Lek Pharmaceuticals d.d.

Conflicts of Interest: The authors declare no conflict of interest.

\section{References}

1. Torosantucci, R.; Schöneich, C.; Jiskoot, W. Oxidation of therapeutic proteins and peptides: Structural and biological consequences. Pharm. Res. 2014, 31, 541-553. [CrossRef]

2. Li, S.; Schöneich, C.; Borchardt, R.T. Chemical instability of protein pharmaceuticals: Mechanisms of oxidation and strategies for stabilization. Biotechnol. Bioeng. 1995, 48, 490-500. [CrossRef]

3. Hovorka, S.W.; Schöneich, C. Oxidative degradation of pharmaceuticals: Theory, mechanisms and inhibition. J. Pharm. Sci. 2001, 90, 253-269. [CrossRef]

4. Ha, E.; Wang, W.; John Wang, Y. Peroxide formation in polysorbate 80 and protein stability. J. Pharm. Sci. 2002, 91, 2252-2264. [CrossRef]

5. Singh, S.R.; Zhang, J.; O’Dell, C.; Hsieh, M.-C.; Goldstein, J.; Liu, J.; Srivastava, A. Effect of polysorbate 80 quality on photostability of a monoclonal antibody. AAPS PharmSciTech 2012, 13, 422-430. [CrossRef]

6. Jaeger, J.; Sorensen, K.; Wolff, S.P. Peroxide accumulation in detergents. J. Biochem. Biophys. Methods 1994, 29, 77-81. [CrossRef]

7. Sarkar, B. Metal protein interactions. Prog. Food Nutr. Sci. 1987, 11, 363-400.

8. McKee, D.J.; Frieden, E. Binding of transition metal ions by ceruloplasmin (ferroxidase). Biochemistry 1971, 10, 3880-3883. [CrossRef]

9. Yamashita, M.M.; Wesson, L.; Eisenman, G.; Eisenberg, D. Where metal ions bind in proteins. Proc. Natl. Acad. Sci. USA 1990, 87, 5648-5652. [CrossRef]

10. Jernigan, R.; Raghunathan, G.; Bahar, I. Characterization of interactions and metal ion binding sites in proteins. Curr. Opin. Struct. Biol. 1994, 4, 256-263. [CrossRef]

11. Stadtman, E.R. Metal ion-catalyzed oxidation of proteins: Biochemical mechanism and biological consequences. Free Radic. Biol. Med. 1990, 9, 315-325. [CrossRef]

12. Stadtman, E.R. Oxidation of free amino acids and amino acid residues in proteins by radiolysis and by metal-catalyzed reactions. Annu. Rev. Biochem. 1993, 62, 797-821. [CrossRef]

13. Marx, G.; Chevion, M. Site-specific modification of albumin by free radicals. Reaction with copper (II) and ascorbate. Biochem. J. 1986, 236, 397-400. [CrossRef] 
14. Zhou, S.; Zhang, B.; Sturm, E.; Teagarden, D.L.; Schöneich, C.; Kolhe, P.; Lewis, L.M.; Muralidhara, B.K.; Singh, S.K. Comparative evaluation of disodium edetate and diethylenetriaminepentaacetic acid as iron chelators to prevent metal-catalyzed destabilization of a therapeutic monoclonal antibody. J. Pharm. Sci. 2010, 99, 4239-4250. [CrossRef]

15. Ji, J.A.; Zhang, B.; Cheng, W.; Wang, Y.J. Methionine, tryptophan, and histidine oxidation in a model protein, PTH: Mechanisms and stabilization. J. Pharm. Sci. 2009, 98, 4485-4500. [CrossRef]

16. Kachur, A.V.; Tuttle, S.W.; Biaglow, J.E. Autoxidation of ferrous ion complexes: A method for the generation of hydroxyl radicals. Radiat. Res. 1998, 150, 475-482. [CrossRef]

17. Biaglow, J.E.; Kachur, A.V. The generation of hydroxyl radicals in the reaction of molecular oxygen with polyphosphate complexes of ferrous ion. Radiat. Res. 1997, 148, 181-187. [CrossRef]

18. Kocha, T.; Yamaguchi, M.; Ohtaki, H.; Fukuda, T.; Aoyagi, T. Hydrogen peroxide-mediated degradation of protein: Different oxidation modes of copper-and iron-dependent hydroxyl radicals on the degradation of albumin. Biochim. Biophys. Acta (BBA)-Protein Struct. Mol. Enzymol. 1997, 1337, 319-326. [CrossRef]

19. Fransson, J.R. Oxidation of human insulin-like growth factor I in formulation studies. 3. Factorial experiments of the effects of ferric ions, EDTA, and visible light on methionine oxidation and covalent aggregation in aqueous solution. J. Pharm. Sci. 1997, 86, 1046-1050. [CrossRef]

20. Guilloreau, L.; Combalbert, S.; Sournia-Saquet, A.; Mazarguil, H.; Faller, P. Redox Chemistry of Copper-Amyloid- $\beta$ : The generation of hydroxyl radical in the presence of ascorbate is linked to redox-potentials and aggregation state. ChemBioChem 2007, 8, 1317-1325. [CrossRef]

21. Lincoln, K.M.; Richardson, T.E.; Rutter, L.; Gonzalez, P.; Simpkins, J.W.; Green, K.N. An N-heterocyclic amine chelate capable of antioxidant capacity and amyloid disaggregation. ACS Chem. Neurosci. 2012, 3, 919-927. [CrossRef] [PubMed]

22. Mao, F.; Yan, J.; Li, J.; Jia, X.; Miao, H.; Sun, Y.; Huang, L.; Li, X. New multi-target-directed small molecules against Alzheimer's disease: A combination of resveratrol and clioquinol. Org. Biomol. Chem. 2014, 12, 5936-5944. [CrossRef] [PubMed]

23. Davies, M.J. Protein oxidation and peroxidation. Biochem. J. 2016, 473, 805-825. [CrossRef] [PubMed]

24. Hermeling, S.; Crommelin, D.J.A.; Schellekens, H.; Jiskoot, W. Structure-immunogenicity relationships of therapeutic proteins. Pharm. Res. 2004, 21, 897-903. [CrossRef]

25. Donbrow, M.; Azaz, E.; Pillersdorf, A. Autoxidation of polysorbates. J. Pharm. Sci. 1978, 67, $1676-1681$. [CrossRef]

26. Kerwin, B.A. Polysorbates 20 and 80 used in the formulation of protein biotherapeutics: Structure and degradation pathways. J. Pharm. Sci. 2008, 97, 2924-2935. [CrossRef]

27. Kishore, R.S.K.; Pappenberger, A.; Dauphin, I.B.; Ross, A.; Buergi, B.; Staempfli, A.; Mahler, H.-C. Degradation of polysorbates 20 and 80: Studies on thermal autoxidation and hydrolysis. J. Pharm. Sci. 2011, 100, 721-731. [CrossRef]

28. Kishore, R.S.K.; Kiese, S.; Fischer, S.; Pappenberger, A.; Grauschopf, U.; Mahler, H.C. The degradation of polysorbates 20 and 80 and its potential impact on the stability of biotherapeutics. Pharm. Res. 2011, 28, 1194-1210. [CrossRef]

29. Dahotre, S.; Tomlinson, A.; Lin, B.; Yadav, S. Novel markers to track oxidative polysorbate degradation in pharmaceutical formulations. J. Pharm. Biomed. Anal. 2018, 157, 201-207. [CrossRef]

30. Knepp, V.M.; Whatley, J.L.; Muchnik, A.; Calderwood, T.S. Identification of antioxidants for prevention of peroxide-mediated oxidation of recombinant human ciliary neurotrophic factor and recombinant human nerve growth factor. PDA J. Pharm. Sci. Technol. 1996, 50, 163-171.

31. Yin, H.; Porter, N.A. New insights regarding the autoxidation of polyunsaturated fatty acids. Antioxid. Redox Signal. 2005, 7, 170-184. [CrossRef] [PubMed]

32. Borisov, O.V.; Ji, J.A.; John Wang, Y. Oxidative degradation of polysorbate surfactants studied by liquid chromatography-mass spectrometry. J. Pharm. Sci. 2015, 104, 1005-1018. [CrossRef] [PubMed]

33. Porter, N.A.; Caldwell, S.E.; Mills, K.A. Mechanisms of free radical oxidation of unsaturated lipids. Lipids 1995, 30, 277-290. [CrossRef] [PubMed]

34. Vittala, P.; Saxena, A.; Bob, M.; Kashibhatta, R.; Ashawat, P.; Ashawat, M. A sensitive LC-ESI-MS/MS method to quantify tibolone as oxime-derivative in human plasma and its application to a pharmacokinetic study. Int. J. Pharm. Pharm. Sci. 2017, 10, 400-419. 
35. Milic, I.; Hoffmann, R.; Fedorova, M. Simultaneous detection of low and high molecular weight carbonylated compounds derived from lipid peroxidation by electrospray ionization-tandem mass spectrometry. Anal. Chem. 2013, 85, 156-162. [CrossRef]

36. Manevich, Y.; Held, K.D.; Biaglow, J.E. Coumarin-3-carboxylic acid as a detector for hydroxyl radicals generated chemically and by gamma radiation. Radiat. Res. 1997, 148, 580-591. [CrossRef]

37. Green, K.N.; Lincoln, K.M.; Gonzalez, P. Antioxidant Small Molecules Aimed at Targeting Metal-Based Oxidative Stress in Neurodegenerative Disorders. U.S. Patent 8969548B2, 3 March 2015.

38. Knez, D.; Sosič, I.; Pišlar, A.; Mitrović, A.; Jukič, M.; Kos, J.; Gobec, S. Biological evaluation of 8-hydroxyquinolines as multi-target directed ligands for treating Alzheimer's disease. Curr. Alzheimer Res. 2019, 16, 801-814. [CrossRef]

39. Mravljak, J.; Jakopin, Ž. Iron-binding and anti-Fenton properties of novel amino-acid-derived cyclic imide dioximes. Antioxidants 2019, 8, 473. [CrossRef]

40. Griffiths, S.W.; Cooney, C.L. Development of a peptide mapping procedure to identify and quantify methionine oxidation in recombinant human $\alpha 1$-antitrypsin. J. Chromatogr. A 2002, 942, 133-143. [CrossRef]

41. Fekete, S.; Ganzler, K.; Fekete, J. Fast and sensitive determination of polysorbate 80 in solutions containing proteins. J. Pharm. Biomed. Anal. 2010, 52, 672-679. [CrossRef]

42. Schöneich, C. Methionine oxidation by reactive oxygen species: Reaction mechanisms and relevance to Alzheimer's disease. Biochim. Biophys. Acta (BBA)-Proteins Proteom. 2005, 1703, 111-119. [CrossRef] [PubMed]

43. Hsu, Y.-R.; Narhi, L.O.; Spahr, C.; Langley, K.E.; Lu, H.S. In vitro methionine oxidation of escherichia coli-derived human stem cell factor: Effects on the molecular structure, biological activity, and dimerization. Protein Sci. 1996, 5, 1165-1173. [CrossRef] [PubMed]

44. Mulinacci, F.; Poirier, E.; Capelle, M.A.H.; Gurny, R.; Arvinte, T. Influence of methionine oxidation on the aggregation of recombinant human growth hormone. Eur. J. Pharm. Biopharm. 2013, 85, 42-52. [CrossRef] [PubMed]

45. Kocijan, A.; Milošev, I.; Pihlar, B. The influence of complexing agent and proteins on the corrosion of stainless steels and their metal components. J. Mater. Sci. Mater. Med. 2003, 14, 69-77. [CrossRef]

46. Zhou, S.; Schöneich, C.; Singh, S.K. Biologics formulation factors affecting metal leachables from stainless steel. Aaps Pharmscitech 2011, 12, 411-421. [CrossRef]

47. Zhang, L.; Yadav, S.; Demeule, B.; Wang, Y.J.; Mozziconacci, O.; Schöneich, C. Degradation mechanisms of polysorbate 20 differentiated by ${ }^{18}$ O-labeling and mass spectrometry. Pharm. Res. 2017, 34, 84-100. [CrossRef]

48. Yao, J.; Dokuru, D.K.; Noestheden, M.; Park, S.S.; Kerwin, B.A.; Jona, J.; Ostovic, D.; Reid, D.L. A quantitative kinetic study of polysorbate autoxidation: The role of unsaturated fatty acid ester substituents. Pharm. Res. 2009, 26, 2303-2313. [CrossRef]

49. Martos, A.; Koch, W.; Jiskoot, W.; Wuchner, K.; Winter, G.; Friess, W.; Hawe, A. Trends on analytical characterization of polysorbates and their degradation products in biopharmaceutical formulations. J. Pharm. Sci. 2017, 106, 1722-1735. [CrossRef]

50. Kranz, W.; Wuchner, K.; Corradini, E.; Berger, M.; Hawe, A. Factors influencing polysorbate sensitivity against enzymatic hydrolysis and oxidative degradation. J. Pharm. Sci. 2019, 108, 2022-2032. [CrossRef]

(C) 2020 by the authors. Licensee MDPI, Basel, Switzerland. This article is an open access article distributed under the terms and conditions of the Creative Commons Attribution (CC BY) license (http://creativecommons.org/licenses/by/4.0/). 